\title{
Mevsimsel Alerjik Konjonktivitli Çocuklarda Sistemik İnflamasyon Biyobelirteçlerinin İncelenmesi
}

\author{
Hanife Tuba AKÇAM 國
}

\section{ÖZ}

Amaç: Oküler alerjinin en sık formu olan mevsimsel alerjik konjonktivit ağırlıklı olarak genç popülasyonu etkilemesi ve son yıllarda artan insidansı nedeniyle dikkat çekmeye devam etmektedir. Daha çok lokal inflamatuar bir konjonktiva hastalığı olduğu düşünülen bu rahatsızlığın sistemik kökenleri belirsizdir. Bu çalışmada mevsimsel alerjik konjonktivitli çocuklarda tam kan sayımı parametreleri ve kan temelli sistemik inflamasyon biyobelirteçlerinin düzeylerinin incelenmesi amaçlanmıştır.

Gereç ve Yöntemler: Mevsimsel alerjik konjonktivit dışında herhangi bir oküler ya da sistemik hastalı̆̆ olmayan 26 çocuk hasta ve yaş-cinsiyet uyumlu 31 sağlıklı gönüllü çalışmaya dahil edildi. Retrospektif olarak olguların son bir ay içindeki hemogram sonuçlarına bakılarak nötrofil sayı/yüzdesi, lenfosit sayı/yüzdesi, hemoglobin, eritrosit sayısı, lökosit sayısı, ortalama trombosit hacmi, eritrosit dağılım genişliği ve trombosit sayıları belirlendi ve nötrofil/lenfosit oranı, trombosit/lenfosit oranı, sistemik immün-inflamasyon indeksi hesaplandı. İstatistiksel değerlendirmede ki-kare testi, bağımsız örneklemler t-testi ve Mann-Whitney U testi kullanıldı.

Bulgular: Gruplar arasında lökosit, eritrosit, trombosit sayı ve yüzdelerinin benzer olduğu görüldü. Hemoglobin, eritrosit dağılım genişliği ve ortalama trombosit hacmi açısından da anlamlı fark saptanmadı. Nötrofil/lenfosit oranı, trombosit/lenfosit oranı ve sistemik immün-inflamasyon indeksi oranları da benzerdi (sırasıyla $\mathrm{P}=0,848 \mathrm{P}=0,276$ ve $\mathrm{P}=0,701$ ).

Sonuç: Mevsimsel alerjik konjonktivitli çocuklarda kan temelli sistemik inflamasyon biyobelirteçlerinin düzeylerinde anlamlı farklılık görülmemiştir. Bu hastalığın sistemik inflamatuar temeline yönelik daha geniş çaplı araştırmalar gereklidir.

Anahtar Kelimeler: Alerji; alerjik konjonktivit; inflamasyon; kan hücresi sayımı; konjonktivit.

\section{Investigation of Systemic Inflammation Biomarkers in Children with Seasonal Allergic Conjunctivitis}

\begin{abstract}
Aim: Seasonal allergic conjunctivitis, the most frequent form of ocular allergy, keeps drawing attention as it predominantly affects the young population and its incidence rate increases recently. The systemic origins of this disorder, which is thought to be a more local inflammatory conjunctival disease, are uncertain. In this study, we aimed to examine the complete blood count parameters and blood-based systemic inflammatory markers in children with seasonal allergic conjunctivitis.

Materials and Methods: 26 children with no ocular or systemic disease apart from seasonal allergic conjunctivitis and 31 age and sex-matched healthy volunteers were included in the study. Retrospectively, by recording the complete blood count for previous month, neutrophil count/percentage, lymphocyte count/percentage, hemoglobin, red blood cell count, white blood cell count, mean platelet volume, red cell distribution width and platelet count were determined and neutrophil/lymphocyte ratio, platelet/lymphocyte ratio and systemic immune-inflammation index were calculated. Chisquare test, independent samples t-test and Mann-Whitney U test were used for statistical evaluation.

Results: The number and percentage of leukocytes, erythrocytes, platelets were observed to be similar in groups. There was no significant difference in terms of hemoglobin, erythrocyte distribution width and mean platelet volume as well.
\end{abstract}

1 Düzce Üniversitesi, Tıp Fakültesi, Göz Hastalıkları AD, Düzce, Türkiye 
Neutrophil/lymphocyte ratio, platelet/lymphocyte ratio and systemic immune-inflammation index were also similar $(\mathrm{P}=0.848 \mathrm{P}=0.276$ and $\mathrm{P}=0.701$ respectively).

Conclusion: No significant difference was observed in the level of blood-based systemic inflammatory biomarkers in children with seasonal allergic conjunctivitis. Further research is required to explore the systemic inflammatory basis of this disease.

Keywords: Allergy; allergic conjunctivitis; blood cell count; conjunctivitis; inflammation.

\section{GíRIŞ}

Alerjik hastalıklarda son yıllarda dramatik bir artış olmuştur. Alerjik göz hastalıkları da klinik pratikte en sık karşılaşılan oküler rahatsızlıklardandır. Bu artışın tek bir nedeni olmayıp atopik yatkınlık/aile hikayesi gibi genetik faktörler, hava kirliliği ve erken çocukluk dönemindeki alerjen maruziyetleri başta olmak üzere birçok faktörün katkısından bahsedilmektedir $(1,2)$. Alerjik konjonktivit; mevsimsel alerjik konjonktivit (MAK), pereniyal alerjik konjonktivit (PAK), vernal keratokonjonktivit (VKK), atopik keratokonjonktivit (AKK), kontakt alerji ve dev papiller konjonktiviti kapsayan genel bir terimdir (3). Alerjik konjonktivit ailesi içinde en sık görülen form olan MAK'ın toplumun yaklaşık \%15-20'sini etkilediği düşünülmektedir. MAK (saman nezlesi konjonktiviti) insidansı ve semptomları bakımından kendisine çok benzeyen ve zaman zaman tanı karmaşasına neden olabilen PAK'dan bazı klinik özellikleri ile ayrılır. Her iki hastalık da kişilerde kaşıntı (ana semptom), kızarıklık, sulanma, göz kapaklarında şişlik, periorbital şişlik (ciddi vakalarda) ve üst tarsal konjonktivada papiller reaksiyon gibi şikayetlere neden olur. Fakat, MAK adı üstünde mevsimsel özellik gösteren bir hastalık olup genellikle ilkbahar ya da yaz aylarında başlar ve kış aylarında söner. Alerjik etken coğrafik bölgeye göre değişmekle birlikte sıklıkla çim/ağaç polenleri gibi özel mevsimsel alerjenlerdir. PAK ise ev tozları ve hayvan tüyleri gibi mevsimsel olmayan alerjenlerden kaynaklanır. PAK'da semptomlar mevsimsel artışlar (en sık sonbaharda) gösterse de yıl boyu devam eder. Mevsimsel tipten daha nadir ve daha az şiddetlidir (4). VKK ve AKK ise bilateral, şiddetli, tekrarlayıcı ve daha kötü prognozlu alerjik konjonktivit formlarıdır. Korneanın da sıklıkla tutulduğu bu alerjik konjonktivit tiplerinin ise yaklaşık $\% 0,01-\% 0,1$ gibi çok daha düşük yaygınlığa sahip olduğu epidemiyolojik çalışma sonuçlarından anlaşılmaktadır $(5,6)$.

MAK alerjik konjonktivitlerin en iyi huylu (benign) formu olmasına rağmen hastaların hayat kalitesi üzerinde ciddi derecede etkilidir, iş verimini düşürür ve sağlık bakım maliyetlerini arttırır. Patojenezinde havada asılı kalan spesifik alerjenlere karşı Th-2 hücreleri (Tyardımc1 hücreleri) tarafindan yönetilen $\operatorname{IgE}$ (immunglobulin E) aracılı tip 1 aşırı duyarlılık reaksiyonu başı çekmektedir. Alerjenlere duyarlı kişilerde maruziyet sonrası akut ya da subakut olarak ortaya çıkan bu reaksiyonda konjonktivadaki mast hücrelerinin degranülasyonu ile histamin ve diğer inflamatuar mediyatörler açığa çıkar. Doku içine ve gözyaşına dağılan mediyatörler lokal inflamatuar yanıtı tetikleyerek konjonktiva damarlarında dilatasyon (konjonktival hiperemi, kırmızı göz), kan damarlarında geçirgenlik artışı (konjonktiva ödemi, kemozis) ve kaşıntıya neden olurlar $(7,8)$.

Daha çok hastalığın lokal inflamatuar temeline yönelmiş birçok araştırmacı oküler yüzeyde ve gözyaşında yaptıkları araştırmalar ile etyopatojenezi aydınlatmaya çalışmışlardır. Fakat bir yandan potansiyel alerjenlere yoğun olarak maruz kalan birçok kişide hiç semptom oluşmazken diğer yandan bazılarında tekrarlayan alerjik konjonktivit atakları yaşanması hatta bir kısmında da alerjik konjonktivite ek olarak alerjik rinit, astım, kontakt dermatit gibi başka sistem bulgularının da eklenmesi, hastalığın ortaya çıkmasında atopik bünye ve genetik yatkınlık gibi iyi bilinen etiyolojik faktörlerin yanında başka kolaylaştırıcı faktörlerin de olabileceğini akla getirmektedir (9). Sistemik inflamasyon da bu muhtemel etyopatojenik faktörlerden birisidir. $\mathrm{Bu}$ çalışmadaki amacımız tam kan sayımı (TKS) parametreleri ve kan temelli sistemik inflamasyon biyobelirteçlerinin MAK hastalarındaki düzeyini incelemektir.

\section{GEREÇ VE YÖNTEMLER}

Göz polikliniğine alerjik konjonktivit semptomları ile başvuran ve anamnez/muayene bulgularına göre MAK olduğu kanaatine varılan 26 çocuk hasta ile 31 yaşcinsiyet uyumlu sağlıklı gönüllü çalışmaya dahil edildi. Tüm hastaların demografik ve klinik özellikleri kaydedildi. Çalışmadan çıkarılma kriterleri; MAK (çalışma grubu için) ve refraksiyon kusuru (kontrol grubu için) dışında sistemik/oküler akut ya da kronik hastalık varlığı, enfeksiyon varlığı, sistemik veya topikal ilaç kullanımı ve göz cerrahisi geçirmiş olmak olarak belirlendi. Kontrol grubu göz polikliniğine refraksiyon muayenesi için başvuran ve refraksiyon bozukluğu dışında oküler/sistemik açıdan tamamen sağlıklı çocuklar arasından seçildi. Tüm olgularda ek sistemik alerjik hastalık (alerjik rinit, alerjik astım, atopik dermatit, vb.) varlığı özellikle sorgulanarak çalışma gurubunda MAK'a ek olarak başka sistemik alerjik hastalık olmadığı, kontrol grubunda da alerjik konjonktivit dahil hiçbir alerjik hastalık olmadığı teyit edildi.

Mevsimsel alerjik konjonktivitin diğer oküler yüzey hastalıklarından ve diğer oküler alerji formlarından ayırıc1 tanisı İspanya Alergoloji Topluluğu (Spanish Society of Allergology) ve İspanya Oftalmoloji Topluluğu (Spanish Society of Ophthalmology)'nun ortaklaşa yayımladıkları DECA (Documento dE Consenso sobre Conjuntivitis Alérgica) raporu referans alınarak yapıldı. Buna göre aile hikayesi, yaş grubu, cinsiyet, mevsimsel ilişki, maruz kalınan alerjenlerin içeriği (ağaç/çim polenleri, ev tozları, hayvan tüyleri, vb.), topikal toksik ajanlara maruziyet, kontakt lens kullanım hikayesi, kaşıntı varlığı, konjonktival hiperemi, fotofobi, akıntı varlığı, göz kapağı tutulumu, korneal tutulum, papiller hipertrofinin varlığı ve düzeyi, görme etkilenmesi, eşlik eden diğer atopik hastalıkların varlığı (rinit, astım, dermatit, vb.) topikal anthistaminik ve/veya topikal mast hücre stabilizatörlerine cevap ve topikal kortikosteroidlere cevap gibi faktörler incelendi (10).

Göz polikliniğine tedavi ya da takip için başvuran hastalara görme keskinliği/refraksiyon muayenesi, göz içi basınç ölçümü, ön ve arka segment muayenesini içeren kapsamlı göz muayenesi yapılıp sistemik hastalık varlığı sorgulandı. İzole mevsimsel alerjik konjonktiviti (çalışma 
grubu için) ve izole refraksiyon kusuru (kontrol grubu için) olan hastalara çalışma ile ilgili detaylı bilgi verilip gönüllü olanların hastane laboratuvar kayıtları retrospektif olarak incelendi. Olguların TKS sonuçları hastane bilgi sistemi üzerinden son bir ay içindeki kan sonuçları taranarak elde edildi. TKS incelemelerinde kullanılan kan örneklerinin verildiği tarih itibariyle sonuçları etkileyebilecek patoloji tarifleyen (enfeksiyon vb.) olgular çalışmadan dişlandı. Son bir aya ait TKS sonucu olmayan hastalardan yeni kan alınmadı. TKS sonuçlarının taranması göz muayenesi ile eş zamanlı olarak ve MAK tedavisi başlanmasından önce yapıldı. TKS sonuçlarına bakılarak nötrofil sayı/yüzdesi, lenfosit say1/yüzdesi, hemoglobin, eritrosit sayısı, lökosit sayıs1, ortalama trombosit hacmi, eritrosit dağılım genişliği, trombosit sayıları belirlendi. Ayrıca nötrofil/lenfosit oranı (NLO), trombosit/lenfosit oranı (TLO) ve sistemik immün-inflamasyon indeksi (SII) hesapland.

\section{Çalışmanın Etik Yönü}

Düzce Üniversitesi Sağlık Uygulama Araştırma Merkezi Müdürlüğü'nden ve Düzce Üniversitesi Göz Hastalıkları Anabilim Dalı Başkanlığı'ndan gerekli yasal izinler ve Düzce Üniversitesi Girişimsel Olmayan Çalışmalar Etik Kurulu'ndan etik kurul izni (Karar No:2019/150) alınarak çalışmaya başlandı. Çalışmaya dahil edilen tüm olgulara ve ebeveynlerine çalışmanın amacı anlatıldıktan sonra Helsinki Bildirgesi'ne bağlı kalınarak yazılı izinleri temin edildi.

\section{İstatistiksel Analiz}

İstatistiksel inceleme SPSS 22 (SPSS Inc, Chicago, IL, USA) analiz programı ile yapıldı. Daha önce yapılan benzer bir çalışma (11) baz alınarak alerjik konjonktivit grubunda ortalama SII değerinin 482,9 $\pm 51,6$ kontrol grubunda ise $526,5 \pm 51,6$ olduğu varsayıldı ve buna göre \%95 güven düzeyi ve \%80 güç ile her bir grup için en az örneklem genişliği 22 olarak hesapland. Denekler basit tesadüfi örnekleme yöntemi ile seçildi. Verilerin normal dağılıma uygunluğunu belirlemede Shapiro-Wilk testi kullanıldı. Normal dağılıma uyan değerler ortalama \pm standart sapma (SS), normal dağılıma uymayan değerler ise ortanca (Q1: 1.kartil- Q3: 3.kartil) şeklinde sunuldu. Niteliksel verilerin karşılaştırılmasında ki-kare testi; niceliksel (ölçümsel) verilerin karşılaştırılmasında ise normal dağılıma uyan verilerde bağımsız örneklemler ttesti, normal dağılıma uymayan verilerde ise MannWhitney $U$ testi kullanıldı. Tüm istatistiksel analiz yöntemlerinde sonuçlar \% 95'lik güven aralığında değerlendirildi. $\mathrm{p}<0,05$ düzeyi anlamlı olarak kabul edildi.

\section{BULGULAR}

Olguların yaşları 3-15 arasında değişiyordu. Alerjik konjonktivit grubunda $10 \mathrm{k} 1 \mathrm{z} 16$ erkek, kontrol grubunda ise $19 \mathrm{kız} 12$ erkek olgu mevcuttu (Tablo 1). 2015 yılında yayımlanan DECA raporunda (10) bildirilen uluslararası sınıflamaya göre olguların hepsinin hafif alerjik konjonktivit grubunda olduğu belirlendi. Bu rapora göre hafif alerjik konjonktivit; intermittan (haftada $\leq 4$ gün veya $\leq 4$ tekrarlayan hafta) ya da persistan (haftada $>4$ gün veya $>4$ tekrarlayan hafta), bıktırıcı olmayan (görmeyi etkilemeyen, okul/iş yaşamını etkilemeyen, günlük yaşam/kitap okuma/sporu engellemeyen) semptom ve bulgular bütünü olarak tanımlanmıştı. Hücre sayıları açısından gruplar benzerdi (Tablo 2). NLO, TLO ve SII için ortanca değerler çalışma grubunda sırasıyla 1,$3 ; 119,5$ ve 482,5 iken kontrol grubunda 1,$5 ; 114,8$ ve 522,6 idi ve gruplar arasinda istatistiksel anlamlı fark yoktu (Tablo 3).

Tablo 1. Demografik veriler

\begin{tabular}{|c|c|c|c|c|}
\hline \multicolumn{2}{|c|}{ Parametreler } & $\begin{array}{c}\text { Alerjik } \\
\text { Konjonktivit } \\
\text { Grubu } \\
(\mathbf{n}=\mathbf{2 6})\end{array}$ & $\begin{array}{c}\text { Kontrol } \\
\text { Grubu } \\
(n=31)\end{array}$ & $\begin{array}{c}\mathbf{P} \\
\text { Değeri }\end{array}$ \\
\hline \multicolumn{2}{|l|}{ Yaş $^{\mathrm{a}}$} & $7(6-11)$ & $8(7-12)$ & $0,233^{b}$ \\
\hline \multirow{2}{*}{$\begin{array}{l}\text { Cinsiyet } \\
\text { (sayı, \%) }\end{array}$} & Kız & $10(38,5 \%)$ & $19(61,3 \%)$ & \multirow{2}{*}{$0,09^{\mathrm{c}}$} \\
\hline & Erkek & $16(61,5 \%)$ & $12(38,7 \%)$ & \\
\hline
\end{tabular}

${ }^{\mathrm{a}}$ : ortanca (Q1: 1.kartil- Q3: 3.kartil), ${ }^{\mathrm{b}}$ : Mann Whitney U testi,

c: Ki-kare önemlilik testi

Tablo 2. Tam kan hücre sayıları

\begin{tabular}{|c|c|c|c|}
\hline Parametreler & $\begin{array}{c}\text { Alerjik } \\
\text { Konjonktivit } \\
\text { Grubu } \\
(n=26)\end{array}$ & $\begin{array}{c}\text { Kontrol } \\
\text { Grubu } \\
(\mathbf{n}=31)\end{array}$ & P Değeri \\
\hline $\begin{array}{l}\text { Nötrofil } \\
\text { Sayısi }^{\text {a }}\end{array}$ & $\begin{array}{c}3,98 \\
(2,90-6,27) \\
\end{array}$ & $\begin{array}{c}4,42 \\
(3,20-5,70)\end{array}$ & $0,712^{b}$ \\
\hline $\begin{array}{l}\text { Nötrofil } \\
\text { Yüzdesic }^{c}\end{array}$ & $53,63 \pm 15,88$ & $53,29 \pm 13,41$ & $0,929^{\mathrm{d}}$ \\
\hline $\begin{array}{l}\text { Lenfosit } \\
\text { Sayısic }^{c}\end{array}$ & $2,75 \pm 1,17$ & $2,9 \pm 0,94$ & $0,580^{\mathrm{d}}$ \\
\hline $\begin{array}{l}\text { Lenfosit } \\
\text { Yüzdesic }^{c}\end{array}$ & $34,27 \pm 14,87$ & $36,18 \pm 12,32$ & $0,598^{\mathrm{d}}$ \\
\hline $\mathbf{R B C}^{\mathbf{a}}$ & $\begin{array}{c}4,80 \\
(4,31-5,03)\end{array}$ & $\begin{array}{c}4,61 \\
(4,41-4,74)\end{array}$ & $0,134^{\mathrm{b}}$ \\
\hline WBC $^{\mathbf{a}}$ & $\begin{array}{c}8 \\
(6,3-9,9) \\
\end{array}$ & $\begin{array}{c}8,5 \\
(6,9-10,1) \\
\end{array}$ & $0,779^{b}$ \\
\hline PLT $^{\mathrm{C}}$ & $333,76 \pm 96,94$ & $318,80 \pm 83,47$ & $0,534^{\mathrm{d}}$ \\
\hline
\end{tabular}

${ }^{\mathrm{a}}$ : ortanca (Q1: 1.kartil- Q3: 3.kartil), ${ }^{\mathrm{b}}$ : Mann-Whitney U testi,

c: ortalama \pm standart sapma; ${ }^{\mathrm{d}}$ : Bağımsız örneklemler t-testi.

$\mathrm{RBC}=$ eritrosit sayıs1, $\mathrm{WBC}=$ lökosit sayısı, $\mathrm{PLT}=$ trombosit sayıs1

Tablo 3. Tam kan sayımı verileri ve bazı oranlar

\begin{tabular}{|c|c|c|c|}
\hline Parametreler & $\begin{array}{c}\text { Alerjik } \\
\text { Konjonktivit } \\
\text { Grubu } \\
(\mathbf{n = 2 6 )}\end{array}$ & $\begin{array}{c}\text { Kontrol } \\
\text { Grubu } \\
\mathbf{( n = 3 1 )}\end{array}$ & P Değeri \\
\hline Hb $^{\mathbf{a}}$ & $12,7 \pm 1,18$ & $12,5 \pm 1,03$ & $0,530^{\mathrm{b}}$ \\
\hline RDW $^{\mathbf{c}}$ & $\begin{array}{c}14,1 \\
(13,1-15,2)\end{array}$ & $\begin{array}{c}13,7 \\
(13,1-14,3)\end{array}$ & $0,160^{\mathrm{d}}$ \\
\hline MPV $^{\mathbf{c}}$ & $\begin{array}{c}7,4 \\
(6,7-8,3)\end{array}$ & $\begin{array}{c}7,8 \\
(7,4-8,4)\end{array}$ & $0,163^{\mathrm{d}}$ \\
\hline NLO $^{\mathbf{c}}$ & $\begin{array}{c}1,3 \\
(0,9-3,2)\end{array}$ & $\begin{array}{c}1,5 \\
(0,9-1,9)\end{array}$ & $0,848^{\mathrm{d}}$ \\
\hline TLO $^{\mathbf{c}}$ & $\begin{array}{c}119,5 \\
(100,4-169,3)\end{array}$ & $\begin{array}{c}114,8 \\
(89,3-148,6)\end{array}$ & $0,276^{\mathrm{d}}$ \\
\hline SII $^{\mathbf{c}}$ & $\begin{array}{c}482,5 \\
(298,4-1197,2)\end{array}$ & $\begin{array}{c}522,6 \\
(244,9-741,2)\end{array}$ & $0,701^{\mathrm{d}}$ \\
\hline
\end{tabular}

${ }^{\text {a }}$ : ortalama \pm standart sapma, ${ }^{\text {b: }}$ Bağımsız örneklemler t-testi, ${ }^{\text {c: }}$ ortanca (Q1: 1.kartil- Q3: 3.kartil), ${ }^{\mathrm{d}}$ : Mann-Whitney U testi, $\mathrm{Hb}=$ hemoglobin, RDW= eritrosit dağılım genişliği,

$\mathrm{MPV}=$ ortalama trombosit hacmi,NLO= nötrofil/lenfosit oran1, $\mathrm{TLO}=$ trombosit/lenfosit oran1, $\mathrm{SII}=$ sistemik immün-inflamasyon indeksi 


\section{TARTIŞMA}

Oküler alerji; insidans, başlangıç yaşı, doğal seyir, klinik sonuçlar ve tedaviye yanıttaki farklılıklar gibi bazı özelliklere göre birbirinden ayrılan geniş bir klinik antiteler bütünüdür (12). Yapılan çalışmalarda toplumun yaklaşık \%40'ında alerjik göz semptomları olduğu gösterilmiştir. Genellikle genç popülasyonu etkilemesi ve prevalansının yıllar içinde yükselmesi oküler alerjiye olan ilginin giderek artmasına neden olmuştur (13). Alerjik hastalıklar gözde MAK ve PAK gibi akut ve hafif formda ya da VKK ve AKK gibi şiddetli ve kronik formda olabilir. Bunlar arasında en yaygın görüleni \%25-43’lük oranıyla MAK'dır (14). Günümüze kadar temel ve klinik bilimler alanlarında yapılan birçok çalışma ile alerjik konjonktivit patojenezinde rol oynayan hücreler, mediyatörler ve immünolojik hadiseler daha iyi anlaşılmaya çalışılmıştır. $\mathrm{Bu}$ çalışmaların sonuçlarına dayanarak bilim dünyası alerjik konjonktivitin temel olarak IgE aracilı mekanizmadan kaynaklanan inflamatuar bir konjonktiva hastalığı olduğu konusunda hemfikirdir (15). Fakat oküler alerji ailesinin farklı hastalık formlarında farklı inflamatuar reaksiyonların devreye girdiği de bir gerçektir. Mesela MAK ve PAK gibi hafif formlarda Th-2 aracılı IgE üretimi ön planda iken VKK ve AKK gibi şiddetli formlarda Th-1 aktivasyonu öne geçmekte, hücresel tip aşırı duyarlılık reaksiyonu (Tip 4) aktive olmakta ve interferon-gama (IFN- $\gamma$ ) seviyesi yükselmektedir. Hatta patojenezdeki yeni gelişmeler AKC ve VKC'de klasik aşırı duyarlılık reaksiyonları yanında nöroinflamasyon ve doğuştan gelen bağışıklık sistemi (doğal bağışıklık)'nin de aktif roller üstlendiğini desteklemektedir (16). Sonuç olarak, günümüzde oküler alerji sınıflaması, tanısı ve tedavisi konusunda görüş birliği olmaması yanında doğal hikayesi, etyopatojenezi ve epidemiyolojik veriler ile ilgili literatür bilgileri de kısıtlı ve çelişkilidir. Oysa hastalığa neden olan immünolojik mekanizmalar, hastalığın klinik özellikleri, ayırıcı tanıların tam olarak anlaşılması ve yeni tedavilerin bulunması klinisyenlerin bu gibi hastalara daha üstün faydalar sağlamasını kolaylaştıracaktır (17).

Alerjik konjonktivit patojenezi baskın olarak IgE aracılı aşırı duyarlılık reaksiyonudur. Sensitize olmuş bir bireyde oküler yüzeyin alerjenle maruziyeti inflamasyonu başlatır. Kimyasallar, polenler, tozlar gibi alerjenler ve mast hücrelerindeki alerjen spesifik IgE reseptörlerinin etkileşimi sonucu mast hücre aktivasyonu ve degranülasyonu olur. Böylece histamin, heparin, kimaz, triptaz, prostoglandinler ve lökotrienler gibi mediyatörler salınır.

Eş zamanlı olarak mast hücreleri vasküler endotel hücrelerinin de aktivasyonuna neden olur ve interselüler adezyon molekülü (ICAM), vasküler hücre adezyon molekülü (VCAM), b-kemokin (C-C) grubunda yer alan RANTES (regulated upon activation normal $\mathrm{T}$ cell expressed and secreted), monosit kemoatraktan protein (MCP)-1 alfa, interlökin-8 (IL-8), eotaksin, makrofaj inflamatuar protein-1 (MIP-1) gibi kemokinler üretilir. Ortaya çıkan bu proinflamatuar durum artmış hücresel infiltrasyon, epitelyal hücre bariyerlerinin yık1lması ve oküler yüzey hasarına giden immün kaskadı tetikler. Böylece erken ve geç inflamatuar alerjik cevap ortaya çıkar. Bu durumun klinik yansıması MAK'ın tipik semptomlarının ortaya çıkmasıdır (18-20).

Alerjik göz hastalıklarının etyopatojenezine dair bu tür immünolojik kaskatlar hayvan modellerinde gösterilmiştir. Fakat mast hücrelerinin akut alerjik reaksiyondaki ana rolü ve eozinofillerin geç başlangıçlı ve kronik alerjiye katkıları gibi bazı anahtar noktalar halen anlaşılamamıştır. Üstelik yapılan çalışmaların çoğu lokal patofizyolojiye odaklanmıştır ve hastalığın sistemik temellerine yönelik çalışma yok denecek kadar azdır (21,22).

Sistemik değerlendirme yapan çalışmalardan bir tanesinde Dadaci ve ark. (23) 35 MAK hastasinda serum oksidatif stres parametrelerini değerlendirmişler ve sonuçta serum malondialdehit ve iskemi-modifiye albümin seviyelerinin kontrol grubuna oranla çalışma grubunda anlamlı olarak daha yüksek olduğunu görmüşlerdir. Buna göre MAK etyolojisinde oksidatif stresin rolünün olabileceği yorumunda bulunmuşlardır. Elbey ve ark. (24) ise 30 VKK hastasinın nötrofil, eozinofil, lenfosit, trombosit say1s1, ortalama trombosit hacmi (MPV) ve nötrofil/lenfosit oranını 30 sağlıklı kontrol ile karşılaştırmışlardır. MPV ve NLO değerlerini istatistiksel olarak anlamlı olmamalarına rağmen VKK grubunda daha yüksek bulan araştırmacılar, bu sonucun adı geçen parametrelerin VKK için yardımcı parametre olarak kullanılabileceği anlamına geldiği iddiasında bulunmuşlardır. Bunlara ek olarak literatürde IgE, sinir büyüme faktörü (NGF), C-C kemokin reseptörü 6 (CCR6), eozinofilik katyonik protein (ECP), çözünebilir vasküler hücre adezyon molekülü-1 (sVCAM-1) ve P maddesi (substance P)'nin alerjik konjonktivitli hastaların serumunda yükseldiğini gösteren araştırmalar da mevcuttur (25-30). Fakat bu çalışmaların hiçbiri tasarımı ve içeriği itibarı ile bizim çalışmamızla karşılaştırılmaya uygun değildir.

NLO, TLO ve SII indekslerinin kardiyovasküler hastalıklar, inflamatuar hastalıklar, enfeksiyöz hastalıklar, çeşitli kanserler ve postoperatif komplikasyonların değerlendirilmesi gibi birçok durumda kullanılabilirliği keşfedilmiştir. Bunlar arasında SII, yakın zamanda tanımlanmış olması bakımından en güncel parametredir. NLO'nun da maküla dejenerasyonu, glokom ve retinal vasküler hastalıklar gibi oküler patolojilerle yakın ilişkisini gösteren çalışmalar mevcuttur $(31,32)$. Lokal inflamasyonun merkezi rol üstlendiği oküler alerji etyopatojenezinde sistemik inflamasyon da potansiyel bir etken konumundadır. $\mathrm{Bu}$ bağlamda çalışmamızda en yaygın görülen oküler alerji formu olan MAK'a sahip çocuklarda kan temelli sistemik inflamasyon biyobelirteçlerinin düzeyi incelenmiştir. Çalışmamızın sonucunda MAK hastaları ve sağlıklı kontrollerde hücre sayıları/yüzdeleri, NLO, TLO oranları ve SII indeksinin benzer olduğu görülmüştür. Buna göre MAK hastalarında sistemik inflamasyonun etyopatolojik bir etken olabileceği düşüncemizi destekleyebilecek bilimsel kanıt elde edilememiştir.

Oküler alerjik hastalıklarda sistemik inflamasyonun rolü güncel ve keşfe muhtaç bir konu olup; C-reaktif protein (CRP), proinflamatuar sitokinler (IL-1 $\beta$, IL-2, IL-6, IL-8, IL-12, IL-17, IFN- $\gamma$, TNF- $\alpha$, vb.), nitrik oksit (NO), lökotrienler, kemokinler, kemokin reseptörleri, fibronektin, plazminojen aktivatör inhibitör-1 (PAI-1, 
prokalsitonin (PKT), eritrosit sedimentasyon h1z1, adenozin deaminaz (ADA) ve eotaksin gibi proinflamatuar proteinler potansiyel araştırma alanlarıdır. Çalışmamızın en önemli eksiklikleri hasta sayımızın nispeten az olması ve göz muayenesi ile tam kan sayımı sonuçlarının eş zamanlı olmamasıdır. Ayrıca olgularımızın hepsinin hafif alerjik konjonktivit olması anlamlı sonuca ulaşmamıza engel olmuş olabilir. MAK ve sistemik inflamasyon arasındaki ilişkinin tam olarak ortaya çıkarılması için daha şiddetli MAK hastaları ile geniş serili, prospektif karakterli ve uzun takip süreli çalışmalar yapılması yerinde olacaktır.

\section{KAYNAKLAR}

1. La Rosa M, Lionetti E, Reibaldi M, Russo A, Longo A, Leonardi S, et al. Allergic conjunctivitis: a comprehensive review of the literature. Ital J Pediatr. 2013; 39: 18.

2. Miyazaki D, Fukagawa K, Fukushima A, Fujishima $\mathrm{H}$, Uchio E, Ebihara $\mathrm{N}$, et al. Air pollution significantly associated with severe ocular allergic inflammatory diseases. Sci Rep. 2019; 9(1): 18205.

3. Bielory L, Frohman LP. Allergic and immunologic disorders of the eye. J Allergy Clin Immunol. 1992; 89(1 Pt 1): 1-15.

4. Kanski JJ. Clinical ophthalmology: a systematic approach. 6th ed. Philadelphia, PA, Pennsylvania: Butterworth- Heinemann; 2007.

5. Bonini S, Coassin M, Aronni S, Lambiase A. Vernal keratoconjunctivitis. Eye (Lond). 2004: 18(4): 34551.

6. Bremond-Gignac D, Donadieu J, Leonardi A, Pouliquen P, Doan S, Chiambarretta F, et al. Prevalence of vernal keratoconjunctivitis: a rare disease?. Br J Ophthalmol. 2008; 92(8): 1097-102.

7. Schröder K, Finis D, Meller S, Wagenmann M, Geerling G, Pleyer U. Seasonal allergic conjunctivitis. Ophthalmologe. 2017; 114(11): 1053-65.

8. Leonardi A, Castegnaro A, Valerio AL, Lazzarini D. Epidemiology of allergic conjunctivitis: clinical appearance and treatment patterns in a populationbased study. Curr Opin Allergy Clin Immunol. 2015; 15(5): 482-8.

9. Mehta R. Allergy and asthma: allergic rhinitis and allergic conjunctivitis. FP Essent. 2018; 472: 11-5.

10. Sánchez-Hernández MC, Montero J, Rondon C, Benitez del Castillo JM, Velázquez E, Herreras JM, et al (SEAIC 2010 Rhinoconjunctivitis Committee; Spanish Group Ocular Surface-GESOC). Consensus document on allergic conjunctivitis (DECA). J Investig Allergol Clin Immunol. 2015; 25(2): 94-106.

11. Akçam H. Konjonktival pterjium etyopatogenezinde sistemik inflamasyonun rolünün değerlendirilmesi. DÜ Sağlık Bil Enst Derg. 2019; 9(3): 145-9.

12. Singh K, Bielory L, Hackensack NJ, Newark NJ. Epidemiology of ocular allergy symptoms in United States adults (1988-1994). Ann Allergy Asthma Immunol. 2007; 98(A22): 34.

13. Maziak W, Behrens T, Brasky TM, Duhme $H$, Rzehak P, Weiland SK, et al. Are asthma and allergies in children and adolescents increasing?: results from ISAAC phase I and phase III surveys in Munster, Germany. Allergy. 2003; 58(7): 572-9.
14. Sacchetti M, Abicca I, Bruscolini A, Cavaliere C, Nebbioso M, Lambiase A. Allergic conjunctivitis: current concepts on pathogenesis and management. J Biol Regul Homeost Agents. 2018; 32(1 Suppl. 1): 49-60.

15. Leonardi S, del Giudice Miraglia M, La Rosa M, Bellanti JA. Atopic disease, immune system, and the environment. Allergy Asthma Proc. 2007; 28(4): 4107.

16. Offiah I, Calder VL. Immune mechanisms in allergic eye diseases: what is new?. Curr Opin Allergy Clin Immunol. 2009; 9(5): 477-81.

17. Bielory BP, O'Brien TP, Bielory L. Management of seasonal allergic conjunctivitis: guide to therapy. Acta Ophthalmol. 2012; 90(5): 399-407.

18. Wong AH, Barg SS, Leung AK. Seasonal and perennial conjunctivitis. Recent Pat Inflamm Allergy Drug Discov. 2009; 3(2): 118-27.

19. Jo-Watanabe A, Okuno T, Yokomizo T. The role of leukotrienes as potential therapeutic targets in allergic disorders. Int J Mol Sci. 2019; 20(14): pii-E3580.

20. Friedlander MH. Ocular allergy. Curr Opin Allergy Clin Immunol. 2011; 11(5): 477-82.

21. Leonardi A, De Dominicis C, Motterle L. Immunopathogenesis of ocular allergy: a schematic approach to different clinical entities. Curr Opin Allergy Clin Immunol. 2007; 7(5): 429-35.

22. Saban DR, Calder V, Kuo CH, Reyes NJ, Dartt DA, Ono SJ, et al. New twists to an old story: novel concepts in the pathogenesis of allergic eye disease. Curr Eye Res. 2013; 38(3): 317-30.

23. Dadaci Z, Oncel M, Oncel Acir N, Sahin E, Borazan M. Oxidative stress parameters and serum magnesium levels in patients with seasonal allergic conjunctivitis. Cutan Ocul Toxicol. 2016; 35(4): 270-4.

24. Elbey B, Yazgan ÜC, Yıldırım A, Karaalp Ü, Şahin A. Vernal keratokonjonktivitli olgularda ortalama trombosit hacmi ve nötrofil/lenfosit oran1. J Clin Exp Invest. 2015; 6(1): 40-5.

25. Shetty R, Sureka S, Kusumgar P, Sethu S, Sainani K. Allergen-specific exposure associated with high immunoglobulin $\mathrm{E}$ and eye rubbing predisposes to progression of keratoconus. Indian $\mathrm{J}$ Ophthalmol. 2017; 65(5): 399-402.

26. Sacchetti M, Bruscolini A, Lambiase A. Neurotrophic factors and nerve growth factor in ocular allergy. Curr Opin Allergy Clin Immunol. 2019; 19(5): 510-6.

27. Chung SH, Chang SY, Lee HJ, Choi SH. The C-C chemokine receptor 6 (CCR6) is crucial for Th2driven allergic conjunctivitis. Clin Immunol. 2015; 161(2): 110-9.

28. Yuksel H, Yilmaz O, Sogut A, Ertan P, Onur E. Correlation of quality of life with clinical parameters and eosinophilic cation protein levels in children with allergic rhinoconjunctivitis. Int Arch Allergy Immunol. 2009; 148(1): 18-22.

29. Uchio E, Ono S, Ikezawa Z, Ohno S. Serum levels of soluble intercellular adhesion molecule-1, vascular cell adhesion molecule-1, and interleukin-2 receptor in patients with vernal keratoconjunctivitis and allergic conjunctivitis. Allergy. 1999; 54(2): 135-41.

30. Lambiase A, Bonini S, Micera A, Tirassa P, Magrini $\mathrm{L}$, Bonini $\mathrm{S}$, et al. Increased plasma levels of 
substance $\mathrm{P}$ in vernal keratoconjunctivitis. Invest Ophthalmol Vis Sci. 1997; 38(10): 2161-4.

31. Faria SS, Fernandes PC Jr, Silva MJ, Lima VC, Fontes W, Freitas-Junior R, et al. The neutrophil-tolymphocyte ratio: a narrative review. Ecancermedicalscience. 2016; 10: 702.

32. Fankhauser CD, Sander S, Roth L, Gross O, Eberli D, Sulser T, et al. Systemic inflammatory markers have independent prognostic value in patients with metastatic testicular germ cell tumours undergoing first-line chemotherapy. Br J Cancer. 2018; 118(6): 825-30. 